\title{
COLONIALIDADE DE GÊNERO E PODER: DA PÓS- COLONIALIDADE À DECOLONIALIDADE ${ }^{1}$
}

\author{
Coloniality of Gender and Power: From Postcoloniality to Decoloniality
}

\author{
Breny MENDOZA \\ California State University, Northridge \\ breny.mendoza@csun.edu \\ Tradução de Aléxia Milena Gusso dos SANTOS \\ Universidade Federal do Paraná \\ ale_milena@yahoo.com.br \\ https://orcid.org/0000-0001-7974-531X
}

\begin{abstract}
RESUMO: Teorias anticoloniais analisam complexas relações de poder entre o colonizador e o colonizado para promover o projeto político da decolonização. Este artigo situa teorias feministas anticoloniais em relação a duas escolas de pensamento anticolonial, a teoria pós-colonial e a teoria decolonial, particularmente a vertente da teoria decolonial desenvolvida pela escola de pensamento Modernidade/Colonialidade da América Latina. Ele compara os principais argumentos teóricos e projetos políticos associados à interseccionalidade, ao feminismo pós-colonial e ao feminismo decolonial que María Lugones fez progredir com seu conceito de colonialidade de gênero. $\mathrm{O}$ texto explora ainda a recepção do trabalho de Lugones na América Latina e as percepções críticas que a teoria decolonial oferece aos projetos de justiça social contemporâneos. PALAVRAS-CHAVE: Colonialidade de gênero; Colonialidade do poder; Feminismo decolonial; Feminismo pós-colonial.
\end{abstract}

\begin{abstract}
Anticolonial theories analyze complex power relations between the colonizer and the colonized to promote the political project of decolonization. This chapter situates anticolonial feminist theories in relation to two schools of anticolonial thinking, postcolonial and decolonial theory, particularly the strand of decolonial theory developed by the modernity/coloniality school of thought of Latin America. It compares key theoretical arguments and political projects associated with intersectionality, postcolonial feminism, and the decolonial feminism that María Lugones has advanced with her notion of the coloniality of gender. The chapter explores the re-
\end{abstract}

\footnotetext{
${ }^{1}$ Publicação original: MENDOZA, Breny. Coloniality of gender and power: from postcoloniality to decoloniality. In: DISCH, Lisa; HAWKESWORTH, Mary (Ed.). The Oxford handbook of feminist theory. Nova Iorque: Oxford University Press, 2016. p. 100-121.
} 
ception of Lugones work in Latin America and the critical insights that decolonial theory offers contemporary social justice projects. KEYWORDS: Coloniality of gender; Coloniality of power; Decolonial feminism; Postcolonial feminism.

\section{INTRODUÇÃO}

O feminismo anticolonial é um projeto teórico e político que desafia práticas imperialistas e colonizadoras do passado e do presente. Este artigo fornece uma genealogia da teoria feminista anticolonial, rastreando sua emergência a partir de ricas tradições de teorias anticoloniais, pós-coloniais e decoloniais, situando-a em relação a outros feminismos de mulheres de $\operatorname{cor}^{2}$ e examinando suas distintivas críticas ao colonialismo, à modernidade, ao Eurocentrismo, ao capitalismo, ao nacionalismo e ao racismo. Examinando temas-chave nos trabalhos de María Lugones, Silvia Rivera Cusicanqui e Rita Segato, o texto é concluído com uma discussão de suas descrições alternativas da modernidade como um processo violento ligado intrinsecamente à construção e à imposição de hierarquias de raça e gênero.

\section{ANTECEDENTES}

O mundo acadêmico anglófono tem tradicionalmente associado lutas anticoloniais a movimentos de libertação nacional projetados para conseguir "independência" e a movimentos de justiça social que surgem no contexto de consolidação de nações após o poder colonial ter sido derrubado. Teorias anticoloniais são associadas a figuras como W. E. B. Du Bois, pensador pan-africano e ativista de direitos sociais nascido nos Estados Unidos, Aimé Césaire (2017) e Frantz Fanon (2006), renomados críticos do colonialismo francês, e Kwame Nkrumah (1964), líder da independência nacional de Gana. Em 1978, entretanto, o crítico literário palestino-americano Edward Said publicou seu trabalho magistral, Orientalismo, expandindo o quadro histórico, a cartografia e a aquisição cultural do colonialismo e transferindo o destaque da teoria anticolonial para a teoria póscolonial. Na década de 1990, o Grupo Sul-Asiático de Estudos Subalternos introduziu

\footnotetext{
${ }^{2}$ Escolhemos traduzir no artigo o termo em inglês of color por "de cor", reiterando a ressignificação positiva deste termo e preferindo-o ao termo "não branco", que coloca a branquitude como único referente ao nomear toda uma multiplicidade étnico-racial. Esses argumentos são defendidos por Tatiana Nascimento em seu artigo "Quem nomeou essas mulheres 'de cor'? Políticas feministas de tradução que mal dão conta das sujeitas negras traduzidas", publicado na revista Translatio (2017), n. 13, p. 127-142.
} 
uma nova geração de teóricos pós-coloniais, incluindo Ranajit Guha, Homi Bhabha, Partha Chatterjee, Dipesh Chakrabarty e Gayatri Chakravorty Spivak.

Em contraste àqueles que se concentram nas práticas coloniais das nações da Europa Setentrional, os estudiosos latino-americanos e caribenhos enfatizaram que o pensamento anticolonial se originou no contexto de um período colonial muito anterior, como uma reação contra a história violenta do colonialismo ocidental inaugurada em 1492. O autor quíchua do século XVI Felipe Guamán Poma de Ayala (1936) e o mestizo peruano Inca Garcilaso de la Vega (2008) escreveram as primeiras críticas ao colonialismo espanhol pela perspectiva do colonizado. O giro decolonial contemporâneo no mundo acadêmico tem sido liderado por estudiosos latino-americanos e caribenhos inicialmente associados com o Grupo Modernidade/Colonialidade, que construíram um acervo de textos datados desde o século XVI até o século XX que oferecem uma reinterpretação radical da relação entre capitalismo e raça. Ao invés de argumentar que o colonialismo foi irrelevante para o desenvolvimento do capitalismo, os trabalhos de José Carlos Mariátegui (2008), por exemplo, um marxista não ortodoxo peruano, argumentaram, já na década de 1920, que a raça era central ao capitalismo e que a acumulação capitalista não poderia ser compreendida sem se considerar a produção das hierarquias raciais. No seu auge, a escola de pensamento da Modernidade/Colonialidade também argumentou que a modernidade e o capitalismo não foram resultado de processos históricos internos à Europa ou intraeuropeus, mas sim consequências históricas do colonialismo. Teóricos decoloniais incluíam o sociólogo peruano Aníbal Quijano, que teorizou o conceito central da decolonialidade, a colonialidade do poder, além dos argentinos Enrique Dussel, amplamente conhecido por sua filosofia da libertação, e Walter Mignolo, um semiólogo que alcançou prestígio com seu livro The darker side of the Renaissance (1995), e do filósofo porto-riquenho Nelson Maldonado-Torres, que desenvolveu o conceito de colonialidade do ser.

\section{EMERGÊNCIA E SUBMERGÊNCIA}

A teoria feminista anticolonial emerge nesse rico contexto intelectual, porém existe às margens dessas críticas ao colonialismo e às margens da teoria feminista. $\mathrm{O}$ trabalho brilhante de Gayatri Chakravorty Spivak, por exemplo, é emblemático de uma complexa marginalização. Diversos teóricos pós-coloniais tentaram revogar a filiação de Spivak ao Grupo Sul-Asiático de Estudos Subalternos. Nas palavras de Vivek Chibber (2013, p. 8), em seu ensaio de 1985, Subaltern studies: deconstructing historiography (em tradução livre para o português, "Estudos subalternos: desconstruindo a historiografia"), 
Spivak "caiu de paraquedas" nos debates do Grupo Sul-Asiático de Estudos Subalternos "como uma visitante indesejável". Em contraste, o Grupo Modernidade/Colonialidade tem sido mais aberto a estudos feministas, frequentemente fazendo esforços para integrar os escritos de feministas de cor estadunidenses em seus trabalhos. Walter Mignolo, por exemplo, cita Gloria Anzaldúa como a musa de "seu conceito" de pensamento de fronteira. Tomando emprestado de Anzaldúa, mas ao mesmo tempo ignorando toda a extensão de sua teorização, Mignolo concebe o pensamento de fronteira como uma epistemologia decolonial que se origina nas formas de saber do colonizado. De acordo com Mignolo, o pensamento de fronteira transcende pensamentos binários e dicotômicos para recuperar os conhecimentos subjugados das garras do eurocentrismo (MIGNOLO, 2003). Traços do pensamento feminista negro estadunidense também são aparentes nas discussões do Grupo Modernidade/Colonialidade sobre a constituição mútua de raça e gênero e a coconstituição de múltiplos sistemas de poder. Contudo, teóricos decoloniais rapidamente dispensam a interseccionalidade como estrutura teórica, substituindo-a pela noção de "heterarquias" de Kontopoulos, que supostamente aborda as múltiplas e heterogêneas hierarquias globais de forma mais adequada, considerando os entrelaçamentos dos processos sociais em diferentes níveis estruturais (GROSFOGUEL, 2010, p. 71). Diversas estudiosas feministas estão presentes nas antologias publicadas pela escola da Modernidade/Colonialidade e são citadas ao longo de suas narrativas, entretanto, a analítica de gênero ocupa um espaço de liminaridade na teoria decolonial. O tratamento recebido pelo conceito de "colonialidade de gênero", criado por María Lugones, é prova disso. Inspirada parcialmente pelos escritos do Grupo Modernidade/Colonialidade, Lugones vê o gênero como sendo tão central à conceitualização da colonialidade do poder quanto a raça era para Quijano, e, consequentemente, como algo a ser igualmente entendido como uma construção colonial. Mesmo incluída em várias publicações do Grupo e tido reconhecimento público, poucos teóricos decoloniais incorporam a "colonialidade de gênero" de Lugones em seus princípios centrais. Resumindo, a teoria feminista pode inspirar homens específicos a seus próprios voos teóricos, mas ainda não alcançou reconhecimento completo como teoria "séria" de forma independente.

O estudo feminista anticolonial vivencia uma marginalização similar por teóricas feministas nas instituições acadêmicas estadunidenses, anglo-americanas e europeias. Com a notável exceção do estudo feminista pós-colonial, que ganhou grande prestígio entre as feministas estadunidenses, outras formas de teorização feminista anticolonial não ocupam uma posição estável dentro da teoria feminista. Teóricas feministas negras há tempos argumentam que seus conceitos teóricos mais inovadores não são tratados como 
"teoria" dentro do feminismo acadêmico. Nikol Alexander-Floyd (2012) argumenta que a análise interseccional tem sofrido tal metamorfose nas mãos do "feminismo branco" que já não serve a seu propósito fundamental de fazer visível a opressão de mulheres de cor nos Estados Unidos. Como argumenta May (2014), o complexo conceito de interseccionalidade é na realidade reduzido a uma abordagem de gênero de eixo único por estudiosos que rejeitam que o foco central da interseccionalidade esteja nas mulheres negras ou que questionam sua validade empírica. Outras estudiosas negras estadunidenses se encontram "falando com as paredes" ou sofrendo uma retaliação epistêmica dentro das instituições acadêmicas feministas dos Estados Unidos e da Europa (MAY, 2014).

Tal retaliação epistêmica é evidenciada quando os trabalhos de feministas chicanas como Gloria Anzaldúa e Chela Sandoval são caricaturizados como política identitária ou posicionados como uma moda passageira a ser suplantada por teorias pós-estruturais mais sofisticadas (ORTEGA, 2006), ou quando teorias feministas decoloniais são qualificadas como feminismos "de mulheres de cor" (ao invés de feminismos propriamente ditos) e segregadas em estudos étnicos, em programas de estudos latino-americanos, nativoamericanos e afro-americanos, onde têm sido amplamente ignoradas ou apropriadas. A política de citações no "feminismo branco" marca a presença dos estudos das mulheres de cor, mesmo quando distorce o conteúdo de suas ideias, falsifica suas genealogias, passa por cima de suas contribuições para a teoria feminista e ressubjuga seu conhecimento (ALEXANDER-FLOYD, 2012, p. 9). Obras escritas por "feministas do Terceiro Mundo" fora dos Estados Unidos são frequentemente consideradas indignas de tradução. Como consequência, seus trabalhos se tornam conhecidos só depois que foram mediados e reimplantados por estudiosos do "Primeiro Mundo".

De uma perspectiva feminista anticolonial, teorias desenvolvidas por mulheres de cor são sujeitas a uma recolonização à medida que suas ideias e conceitos centrais lentamente desaparecem ou reaparecem "embranquecidos" e desprovidos de seu ímpeto crítico. Um dos objetivos do recente discurso feminista decolonizador é contra-atacar essa retaliação epistêmica, recuperando o trabalho teórico feito por mulheres de cor previamente colonizadas. Parte desse esforço envolve a criação de uma lente multidimensional que possa servir como uma base para o feminismo decolonial e como uma política de coalizão entre mulheres de cor (SANTA CRUZ FEMINIST OF COLOR COLLECTIVE, 2014). Outra medida envolve a recuperação de métodos e estratégias que se justaposicionem dentro de diferentes teorizações desenvolvidas por feministas de cor que resistem ao capitalismo global e ao neocolonialismo (ROSHANRAVAN, 2014). 
Quando a crítica ao capitalismo e ao neocolonialismo é considerada central ao projeto feminista decolonial, se torna claro que o feminismo de mulheres de cor não é consubstancial ao feminismo decolonial, ainda que seja uma parte importante dele. Feministas de cor forneceram alguns elementos base para o feminismo decolonial, mas eles não esgotam suas possibilidades. Os estudos de mulheres de cor não são um gênero unificado e não compartilham de um único projeto intelectual ou político (ROSHANRAVAN, 2014). Tampouco as afirmações epistêmicas e consideráveis de mulheres de cor necessariamente implicam efeitos decolonizadores. Portanto, identificar o que conta como teoria feminista decolonial dentro e além dos estudos das feministas de cor é um assunto complicado. Como Eve Tuck e K. Wayne Yang $(2012$, p. 1) apontam, "desejos decoloniais articulados por povos brancos, não brancos, imigrantes, póscoloniais e oprimidos" frequentemente reduzem a decolonização a uma metáfora para vagos anseios de libertação ou transformação social. Discursos decolonizadores pouco claros e rudimentares correm o risco de reinstalarem normas coloniais, fortalecendo-as ao invés de enfraquecê-las (TUCK; YANG, 2012). A decolonização não é uma metáfora para críticas antirracistas e anticapitalistas, nem para críticas ao eurocentrismo.

Teorias anticoloniais são definidas por critérios ligados a projetos políticos que levam à decolonização. Mas as perguntas: quais critérios e quais projetos políticos levam à decolonização? O que conta como decolonização? E quais práticas conseguem desafiar o colonialismo e a colonialidade? são debatidas incessantemente. Alguns sugerem que o objetivo da teoria feminista anticolonial é principalmente analisar e desafiar impulsos imperialistas e colonizadores dentro das teorias feministas dominantes. Outros sugerem que a teoria anticolonial deve influenciar práticas políticas no terreno. Algumas estudiosas feministas anticoloniais investigam as relações entre raça, gênero e colonização e entre raça, gênero e o Estado-nação moderno. Especificamente, um assunto que sofre intensa contestação é de que forma a análise interseccional está situada em relação à teorização feminista das hierarquias criadas e mantidas pelo colonialismo.

No restante desse artigo desenvolvo um quadro provisório para o entendimento de projetos teóricos e políticos dos feminismos anticoloniais. Para localizar a interseccionalidade, o feminismo pós-colonial e o feminismo decolonial em relação ao projeto de decolonização, começo analisando suas relações com as principais correntes da teoria pós-colonial e decolonial, campos que continuam a ser dominados por estudiosos homens. 


\section{INTERSECCIONALIDADE E TEORIA ANTICOLONIAL}

Embora muitas estudiosas feministas considerem a interseccionalidade um conceito revolucionário que redefiniu abordagens teóricas, políticas e metodológicas (MCCALL, 2005; HANCOCK, 2011; CHO; CRENSHAW; MCCALL, 2013), este conceito, desenvolvido por pensadoras feministas negras, esteve sob forte escrutínio durante a década passada. Seu valor epistêmico foi questionado por estudiosas feministas pós-estruturalistas que o acusam de ser "meramente descritivo" (JORDAN-ZACHERY, 2007 citada por ALEXANDER-FLOYD, 2012, p. 5). Longe de oferecer algo novo, críticas sugeriram que a interseccionalidade replica os problemas de longa data da política identitária, dando ênfase exagerada a categorias de identidade descontextualizadas, limitando-se a focar em um pequeno subconjunto de limitações estruturais, ou enfatizando de modo exagerado o racismo dentro do feminismo. Outras críticas sugerem que a interseccionalidade enfraquece a coerência filosófica e política do feminismo por desafiar a primazia da opressão de gênero, por estigmatizar a categoria "mulher", ou por fazer circular narrativas que são incapazes de tratar da complexidade do social (ZACH, 2005; GUNNARSON, 2011 citada por MAY, 2014, p. 102).

Algumas estudiosas tentaram "corrigir" as supostas limitações da análise interseccional associadas ao foco exclusivo na opressão de mulheres de cor reimplantando o método para o estudo de todas as mulheres, ou, de fato, de todas as pessoas (GARRY, 2012). Mas algumas teóricas feministas negras resistem à inflação conceitual da interseccionalidade que contenha qualquer estudo de fatores múltiplos de poder (por exemplo, branquitude, classe social e religião), porque isso tem o efeito de apagar as mulheres de cor e de trazer as mulheres brancas novamente ao centro da análise. Outras estudiosas tentaram corrigir os "problemas" da interseccionalidade recuperando análises de eixo único que investigam as dinâmicas de gênero ou classe social, ou escavando complexos contextos sócio-históricos, dinâmicas localizadas e processos institucionais, ou evitando a lógica categorial e adotando abordagens polivalentes e multiníveis (MAY, 2014, p. 104).

Algumas dessas "correções" envolvem pouco mais do que a adoção superficial de uma abordagem aditiva, o que torna ininteligível a coconstituição dos sistemas de poder - gênero, raça, etnia, classe social, sexualidade, nacionalidade -, assim enfraquecendo a premissa fundamental da análise interseccional. Portanto, não é surpreendente que muitas teóricas feministas negras interpretem essas críticas desdenhosas e as deturpações da interseccionalidade como violência epistêmica e como recolonização do conhecimento feminista negro. 
Em contraste à rejeição e à distorção da interseccionalidade, estudos póscoloniais e decoloniais, dentro e fora dos Estados Unidos, incorporaram o conceito. Um quadro interseccional tem sido central para feminismos do Terceiro Mundo críticos ao colonialismo - feminismos tipicamente classificados como pós-coloniais (MOHANTY; RUSSO; TORRES, 1991). Por exemplo, em Couro imperial, Anne McClintock (2010 [1995]), uma feminista branca pós-colonial nascida no Zimbábue e criada na África do Sul, argumenta que o colonialismo e o imperialismo não poderiam ser entendidos sem considerarmos a invenção da raça. Para McClintock, a análise interseccional reconhece que sistemas de poder fundamentados no gênero, na raça, na classe social e na sexualidade não são esferas de experiência distintas e isoladas, mas se entrelaçam perigosamente, não apenas no colonialismo britânico, mas também nas lutas anticoloniais. Como o Santa Cruz Feminist of Color Collective (2014, p. 33) já observou, a teoria feminista anticolonial leva a interseccionalidade além das críticas das práticas legais do Estado para esclarecer dinâmicas "glocalizadas" - interpenetrações do global e do local que constroem o gênero, a raça, a classe social e a sexualidade, não como categorias independentes, mas como sistemas de poder mutuamente constituintes que existem dentro e através de relações contraditórias e conflitantes.

As fronteiras do feminismo pós-colonial têm sido porosas e sujeitas a contestação nas últimas duas décadas. Diversas antologias incluem os escritos do feminismo negro e chicano dentro da teoria feminista pós-colonial, publicando esses textos clássicos junto a escritos de feministas de Terceiro Mundo alinhadas ao Grupo Sul-Asiático de Estudos Subalternos, e de feministas que promovem críticas ao Orientalismo (LEWIS; MILLS, 2003). Abordagens inclusivas como essa deixam claro que a análise interseccional sempre foi central ao feminismo pós-colonial. Mas homogeneizar diferentes tradições de teorizações feministas feitas por mulheres de cor sob a rubrica do feminismo póscolonial também traz riscos; mais evidentemente, o risco de perder de vista o que é mais central à teoria feminista anticolonial. A teoria pós-colonial implica um programa teórico e político que não deve ser confundido com outras abordagens teóricas. Existem importantes diferenças teóricas e práticas entre o feminismo negro, o feminismo chicano e o feminismo pós-colonial. Esses quadros teóricos se originam de experiências e períodos coloniais diferentes e têm objetivos de pesquisa diferentes. Ocupando diferentes posições de sujeito dentro de quadros nacionais, globais e acadêmicos, os estudiosos e ativistas que contribuem para o discurso da interseccionalidade têm diversos interesses na colonialidade e diversas relações com ela. Emergindo de diferentes tradições teóricas e englobando diferentes projetos políticos, a teoria feminista negra, a teoria feminista 
chicana e a teoria feminista pós-colonial estão longe de ser uniformes. Em vez de presumir visões em comum, é importante investigar se uma crítica de colonialidade e um projeto decolonial em particular subjazem análises interseccionais específicas.

Conforme tem sido bem documentado, as raízes intelectuais da análise interseccional são fundamentadas na observação feita por teóricas feministas negras acerca da opressão sofrida por mulheres negras nos Estados Unidos, o que enfatizou as complexas inter-relações de raça, classe social, gênero e expropriação. O conceito foi primeiro encontrado, no começo do século XIX, nos discursos da abolicionista e agitadora política Maria Stewart (1803-1880), e depois nos estudos de Anna Julia Cooper (18581964), cujas visões de mundo foram moldadas pelo sistema de escravidão, estabelecido e apoiado pela lei estadunidense, e também pela luta para a abolição desse sistema. Na segunda metade do século XX, o Coletivo Combahee River teorizou as intersecções de sexualidade, raça, gênero e classe social. Kimberlé Crenshaw (1989) cunhou o termo "interseccionalidade" em sua investigação sobre a falha das cortes dos Estados Unidos em reconhecer discriminações baseadas tanto em raça quanto em gênero. Patricia Hill Collins $(1993 ; 2019)$ teorizou o ponto de vista feminista negro como uma ferramenta intelectual crucial com a qual iluminar as complexas opressões de mulheres contemporâneas nos Estados Unidos. Nesses contextos, a interseccionalidade serviu não só para fazer visíveis as dimensões da opressão de mulheres negras que tinham sido mascaradas pela suposição da mulher como uma categoria unitária dentro da teoria feminista, mas também serviu para desafiar concepções paradigmáticas de raça apresentadas pela teoria crítica previamente desenvolvida por homens. Enfatizando os vetores multidimensionais de poder que estruturaram tanto as identidades vividas quanto a realidade social, a interseccionalidade iluminou os laços entre lugar epistêmico e produção de conhecimento, e ofereceu estratégias analíticas que uniam o material, o discursivo e o estrutural. Demonstrando as inadequações nos jeitos de pensar "ou-isto-ou-aquilo" (binários) e a futilidade dos esforços para hierarquizar opressões, a interseccionalidade reflete as lições que teóricas feministas negras estadunidenses aprenderam das experiências vividas de mulheres negras, sejam elas de escravidão, desenraizamento e expropriação, exploração econômica e reprodutiva, segregação da era de Jim Crow, sharecropping e trabalho doméstico, linchamento, estupro, motins raciais, cidadania de segunda classe e racismo sistêmico disfarçado de igualdade formal.

Quando implantado por diversas estudiosas feministas negras contemporâneas que vivem nos Estados Unidos, o projeto político da interseccionalidade permanece ligado ao estado de colonização de povoamento estadunidense. Historiadores usaram a análise 
interseccional para demonstrar como opressão sexual e de gênero foram essenciais para a constituição da escravidão e do sistema de plantation. Economistas políticos mostraram como a escravidão e o sistema de plantation forneceram um modelo, uma planta baixa persistente para as relações econômicas e sociais nos Estados Unidos, que continua a mapear a guetização, a segregação educacional e o complexo industrial-prisional. Teóricos sociais traçaram a maneira pela qual os legados da escravidão e do apartheid racial legal se tornaram associados a corpos negros, influenciando perspectivas de vida pessoais, relações sexuais, formação de família, oportunidades econômicas, possibilidades residenciais e empregatícias, forjando laços duradouros entre os contextos colonial e pós-colonial dos Estados Unidos. Dentro desse contexto histórico e intelectual, a interseccionalidade frequentemente nutre demandas políticas por inclusão e direitos iguais, demandas por cidadania completa que são vistas como cruciais para se viver uma vida em liberdade.

Certas inflexões da política interseccional, portanto, se mostram favoráveis a uma política liberal de inclusão, o que enfraquece o potencial decolonizador da interseccionalidade. Noções liberais de liberdade, igualdade e justiça tiradas da Declaração de Independência e da Constituição dos Estados Unidos surgem como precondição para a futuridade de mulheres e homens negros estadunidenses, precisamente porque a eles foram recusadas as "bênçãos da liberdade". Contudo, ao abraçar a inclusão liberal como um projeto político, a interseccionalidade sugere estratégias de ação e resultados preferíveis que a alienam de outras lutas anticoloniais fora dos Estados Unidos. Apesar de sua influência formativa na teorização pós-colonial, os objetivos políticos de teóricas feministas negras estadunidenses com frequência divergem significantemente dos objetivos das lutas anticoloniais na maior parte do mundo.

Entretanto, quando adotada como uma estratégia analítica por feministas anticoloniais fora dos Estados Unidos, a interseccionalidade identifica novos problemas e inesperadas possibilidades políticas que emergem da complexidade das intersecções de gênero, raça, classe social e sexualidade dentro da condição colonial.

\section{DEBATES PÓS-COLONIAIS/DECOLONIAIS E TEORIA FEMINISTA}

\section{Pós-colonialismo}

Na década de 1990, o "colonial” reemergiu nas teorias social, cultural e política. Após o declínio do marxismo, o advento do pós-modernismo/pós-estruturalismo e as teorias culturais pós-marxistas, a teoria pós-colonial ofereceu sofisticadas críticas ao capitalismo, à modernidade e ao colonialismo ocidental. Inspirados por filósofos franceses 
como Michel Foucault e Jacques Derrida, os teóricos pós-coloniais mudaram os termos com que pensamos sobre colonialismo, capitalismo e nacionalismo. Concentrando-se na história do colonialismo britânico e seu colapso nas consequências da Segunda Guerra Mundial, pensadores pós-coloniais procuraram criar uma historiografia alternativa que desafiasse as teorias dominantes de análise histórica no Ocidente. Substituindo o materialismo histórico por uma "história vista de baixo" (CHIBBER, 2013), estudiosos pós-coloniais criaram um novo quadro teórico para o estudo da história colonial, o que ofereceu uma explicação não apenas para a particularidade do capitalismo colonial da Índia, mas também para as operações do capitalismo em outras partes do mundo colonizado. Entretanto, pelo fato de que o Grupo Sul-Asiático de Estudos Subalternos se concentrava principalmente na colonização da Índia e de outras partes da Ásia, suas visões sobre a relação entre colonialismo e capitalismo diferiam drasticamente das visões do Grupo Latino-Americano Modernidade/Colonialidade, que se baseava nas fases mais anteriores da colonização e decolonização espanhola, portuguesa e francesa. Diferenças determinantes nas visões sobre colonialidade, modernidade e capitalismo se tornaram marca registrada não só dessas duas escolas - pós-colonial e decolonial - de estudo anticolonial, mas também de suas equivalentes feministas.

Os subalternistas, frequentemente considerados o grupo central dentro da teoria pós-colonial, argumentam que o capitalismo assumiu formas marcadamente diferentes na Europa e no mundo colonial. Em contraste ao papel "modernizador" que o capitalismo interpretou na Europa, transformando economias agrícolas em economias industriais e alinhando interesses burgueses e proletários na derrubada da aristocracia feudal, os efeitos do capitalismo no Sul da Ásia foram bifurcados. De acordo com os subalternistas, nem as forças progressistas, nem a força universalizadora se materializaram completamente no subcontinente porque elites nacionalistas falharam em modificar o "atraso" do campesinato no processo de colonização (CHIBBER, 2013). Em termos gramscianos, os colonizadores britânicos e a classe capitalista nacionalista indiana foram incapazes ou não estiveram dispostos a ampliar seus interesses particulares às classes subalternas que eles exploravam. Apesar de mudanças superficiais nas leis, o regime antigo e o sistema de castas permaneceram intactos. Em contraste à experiência europeia, onde a retórica dos direitos universais recrutou as classes trabalhadoras exploradas para o projeto político da democracia liberal, na Índia colonial a dominação capitalista envolvia o mandato sem o consenso do governado, isto é, sem hegemonia (CHIBBER, 2013, p. 13). Como consequência da longa história de dominação colonial britânica, visões liberais de igualdade, liberdade política, secularismo e contratualismo não se enraizaram na Índia, 
alterando profundamente o contexto pós-colonial. Até mesmo depois da independência, formas pré-capitalistas de exploração e dominação permaneceram em vigor. Esse desenvolvimento "anormal" do capitalismo dividiu a sociedade pós-colonial em dois domínios políticos, movidos por duas lógicas diferentes e dissonantes: ao passo que a classe capitalista funcionava de acordo com a busca racional do interesse individual, o subalterno era atolado numa forma de política pré-moderna, preocupado com noções de religião, casta, etnicidade e comunidade. Essa configuração singular de classes, de acordo com os subalternistas, distinguiu a modernidade colonial e o capitalismo na Índia, garantindo que tivessem pouca semelhança com o capitalismo e a modernidade europeus. $\mathrm{Na}$ ausência de uma hegemonia, elites anticoloniais nacionalistas construíram uma forma fictícia de Estado-nação pós-colonial baseada numa falsa legitimidade (CHIBBER, 2013, p. 17). Precisamente porque o modelo do desenvolvimento capitalista na Índia diferiu significantemente do europeu, os subalternistas argumentaram que as categorias ocidentais de análise, e a teoria marxista em particular, eram inapropriadas para entendermos o capitalismo colonial no Oriente.

Informados por críticas pós-estruturais a teorias totalizantes como o determinismo econômico, os Estudos Subalternos promoveram uma narrativa alternativa do capitalismo que evitava "narrativas grandiosas". Atentos ao poder do discurso, eles contavam com análises textuais para criar críticas ao colonialismo e ao capitalismo que complementaram as discussões de exploração e dominação com investigações sobre marginalidade e subalternidade (CHIBBER, 2013, p. 8). Ecoando certos esforços da crítica pós-estruturalista à modernidade, a crítica dos subalternistas ao eurocentrismo rejeitou afirmações universalizantes e enfatizou a diferença e o local. Eles destacaram a especificidade cultural "do Oriente" e usaram análises culturais e históricas para teorizar "o subalterno" e levantar questões referentes à sua voz e à sua agência. De acordo com Vivek Chibber (2013, p. 8), Gayatri Chakravorty Spivak, talvez a mais conhecida teórica feminista pós-colonial, foi indiretamente responsável por essas características únicas da crítica pós-colonial.

\section{Feminismo pós-colonial}

Como fundadora e, por vezes, ostracizada do Grupo Sul-Asiático de Estudos Subalternos, diz-se que Spivak caracteriza a si mesma como uma "mosca-na-sopa práticodesconstrutora-marxista-feminista" (LEITCH, 2010, p. 2110). Criticando severamente os subalternistas por deixar de examinar gênero e sexualidade em seus relatos da condição pós-colonial, Spivak promoveu análises das divisões de trabalho dentro do capitalismo sob Revista X, v. 16, n. 1, p. 259-289, 2021. 
a perspectiva do gênero, críticas ao eurocentrismo na literatura ocidental, interrogações sobre as fronteiras epistêmicas e políticas construídas pelo capitalismo global neoliberal, junto a críticas incisivas à erudição feminista ocidental liberal e radical. Usando a análise textual e a crítica cultural como suas principais ferramentas analíticas, Spivak é reconhecida por suas sofisticadas críticas às teorias pós-estruturais, pós-coloniais e feministas e também por suas análises do capitalismo colonial e da política pós-colonial.

Em seu ensaio pioneiro, “Pode o subalterno falar?”, Spivak (2018 [1985]) estabeleceu os termos da crítica feminista pós-colonial. Conceitualizando a "violência epistêmica" como noção integral à produção de conhecimento ocidental, Spivak demonstrou como a produção discursiva do subalterno, particularmente da "mulher do Terceiro Mundo" pobre, silenciou as mulheres do Sul global através de uma forma de ventriloquismo. Sob o disfarce de dar voz ao oprimido, discursos ocidentais acadêmicos e ativistas substituíram as visões orientalistas de mulheres do Terceiro Mundo pelas realidades vividas da existência subalterna. Spivak sugeriu que toda tentativa de representar a mulher subalterna era uma forma de afirmar a superioridade do Ocidente sobre o não-Ocidente. Através da justaposição da "civilização" ocidental contra a "barbárie" do "Oriente", acadêmicos e ativistas colonizaram a experiência subalterna, ao mesmo tempo reforçando a superioridade do conhecimento ocidental. Situando a violência epistêmica na dinâmica da representatividade, Spivak levantou a possibilidade de que a mulher subalterna nunca poderia ser conhecida em seus próprios termos. Ao dar esse passo, também questionou a validez das práticas dentro do Grupo Sul-Asiático de Estudos Subalternos. De fato, ela sugeriu que os teóricos pós-coloniais, ao se posicionarem como conhecedores e portavozes dos subalternos, violaram as premissas fundamentais da crítica pós-colonial. É certo que Spivak afirmou que os teóricos pós-coloniais não apenas deixaram de fornecer uma alternativa ao orientalismo das teorias ocidentais, mas também reproduziram discursos orientalistas ao julgar o subalterno como inerte, inescapavelmente oprimido e essencialmente "Outro" em relação aos sujeitos ocidentais.

Em Under Western eyes (em tradução livre para o português, "Sob olhares ocidentais"), Chandra Talpade Mohanty (1991) trouxe a força total da crítica feminista pós-colonial para abalar os estudos feministas ocidentais. Tomando a Third World Series publicada pela Zed Press como seu ponto de partida, Mohanty (1991a, p. 56) demonstrou como construções binárias de mulheres do Primeiro Mundo e do Terceiro Mundo homogeneizaram as mulheres de ambos os lados do binário, com consequências particularmente negativas para mulheres do Terceiro Mundo, que foram imaginadas como sendo perenemente "ignorantes, pobres, sem instrução, ligadas à tradição, 
domesticadas, direcionadas à família, vitimizadas". Em contraste, mulheres brancas foram uniformemente construídas como "educadas, modernas, tendo controle sobre seus próprios corpos e sexualidades e a liberdade de tomarem suas próprias decisões". Essas oposições discursivas não eram apenas eurocêntricas, mas também, como observou Leela Gandhi (1998), fortaleciam uma imagem de uma redentora plenitude ideológica e política do feminismo ocidental. Parafraseando a denúncia de Spivak sobre os relatos de homens brancos de seus próprios atos coloniais como missões de resgate benevolentes nas quais "homens brancos salvam mulheres de pele escura ${ }^{3}$ de homens de pele escura", Mohanty rechaçou feministas acadêmicas ocidentais que se imaginavam como "mulheres brancas salvando mulheres de pele escura de homens de pele escura”. Embora algumas estudiosas criticassem Mohanty por homogeneizar o feminismo ocidental, sua análise foi impressionantemente profética, antecipando a concepção de mulheres mulçumanas como vítimas dos homens mulçumanos em urgente necessidade de resgate nos discursos pós11 de setembro veiculados não apenas pelas principais feministas estadunidenses, mas também pelo governo dos Estados Unidos, pela mídia ocidental e por organizações de direitos humanos (ABU-LUGHOD, 2012).

Mohanty também expandiu sua concepção de mulheres do Terceiro Mundo além das cartografias estabelecidas pelo Grupo de Estudos Subalternos. Em sua análise do capitalismo global, traçou paralelos entre os heteropatriarcados ocidentais e nãoocidentais, que operavam a fim de maximizar a exploração do trabalho de mulheres do "Terceiro Mundo", quer essas mulheres trabalhem no Sul global ou no Norte global. Em suas buscas para maximizar lucros através do incentivo ao consumo e do fornecimento de mercadoria barata a consumidores ricos, Mohanty sugeriu que as corporações multinacionais aumentavam a precariedade de vida, diminuindo salários de trabalhadoras no Sul, aumentando o desemprego no Norte e fazendo proliferar as sweatshops nas cidades globais do Norte e do Sul. Criando um "contexto comum de lutas políticas" e alimentando "interesses em comum" através de uma exploração brutal, o capitalismo global estava construindo uma base para a solidariedade transnacional entre mulheres do Terceiro Mundo.

Apesar da importância de suas contribuições para a teoria feminista pós-colonial e para o feminismo transnacional, Mohanty não resolve as relações de poder entre mulheres do Primeiro e do Terceiro Mundo que ela analisa tão habilmente em Under Western eyes (MENDOZA, 2002). Embora veja as mulheres do Terceiro Mundo como sujeitos revolucionários, não chega a explicar como os interesses em comum dessas

\footnotetext{
${ }^{3}$ No original, brown women. O termo aqui se refere a sujeitos do Oriente Médio e Ásia Meridional. Revista X, v. 16, n. 1, p. 259-289, 2021. 
mulheres, que vivem na colônia e em centros metropolitanos, podem ser transformados em lutas políticas em comum contra a destrutividade do capitalismo global. Sua ênfase na potencial solidariedade entre mulheres do Terceiro Mundo entre fronteiras subestima a dificuldade de mobilizações feministas transnacionais que tentam unir mulheres do Primeiro e do Terceiro Mundo, ou mulheres brancas e mulheres de cor. Ao sugerir que projetos transformativos nascem da experiência de uma opressão sistêmica, Mohanty faz eco aos esquerdistas tradicionais no Ocidente que imaginam que a revolução começa sempre com os mais marginalizados, o que impõe um fardo enorme sobre as mulheres subalternas. Ao concentrar-se nas opressões compartilhadas que abrangem as fronteiras nacionais e a geopolítica do Norte/Sul, Mohanty também se distancia dos argumentos do Grupo de Estudos Subalternos, que posicionam o subalterno como um ator político motivado por um conjunto de interesses que são radicalmente diferentes dos interesses do Ocidente (CHIBBER, 2013, p. 22). Ao invés de engajar a alteridade do subalterno, a orientação feminista transnacional de Mohanty se alinha mais próxima dos clamores marxistas convencionais por uma solidariedade proletária transnacional como a base para a transformação social.

Em seus esforços para tratar do eurocentrismo e do racismo dentro do feminismo ocidental, estudiosas feministas pós-coloniais desenvolveram não só análises interessantes sobre o viés eurocêntrico encontrado na cultura popular, no cinema e na mídia de massa, como também críticas potentes ao racismo e à racialização na visão dos nacionalistas e dos excepcionalistas estadunidenses, dos sionistas e das elites nacionalistas pós-coloniais (SHOHAT; STAM, 2006; FERNANDES, 2013). Investigando a intersecção de gênero, raça, classe social, sexualidade e nacionalidade, elas ofereceram ótimos estudos sobre as dinâmicas de poder que operam em diferentes contextos coloniais (MCCLINTOCK, 2010; STOLER, 2002). Através do estudo dos sistemas raciais construídos dentro de contextos coloniais particulares, estudiosas feministas pós-coloniais também abriram possibilidades de diálogo com outras teóricas anticoloniais, cujos trabalhos examinam o colonialismo espanhol e português ao invés do colonialismo britânico e francês ou do imperialismo estadunidense (STAM; SHOHAT, 2012). A erudição e a riqueza da pesquisa feminista pós-colonial não podem ser questionadas.

Ainda assim, o feminismo pós-colonial sofre de algumas limitações associadas com a teoria pós-colonial e o pós-estruturalismo convencionais. Como sua corrente convencional equivalente, a teoria feminista pós-colonial tem sido acusada de determinismo e historicismo culturais. O projeto político das feministas pós-coloniais é, além disso, difícil de entender. Embora tenham enfatizado o papel do subalterno e do 
transnacionalismo nas lutas contra o capitalismo global, depositando pouca esperança no potencial emancipatório do Ocidente, teóricas feministas pós-coloniais também expressaram preocupações crescentes sobre a capacidade do subalterno de dar uma reviravolta na sua condição colonial, particularmente em sua presente instanciação como capitalismo global neoliberal. De fato, como Spivak (citada por PAUDYAL, 2011) recentemente observou em uma palestra em Katmandu, no Nepal, o subalterno tem sido "hegemonizado para aceitar sua miséria como normal". Mas se é assim, o que fazer com o projeto do intelectual pós-colonial de "treinar a imaginação" do subalterno para ajudálo/ajudá-la a recuperar o compasso moral perdido para o capitalismo neoliberal global? Afirmações sobre a resignação do subalterno à miséria revelam a distância social que o separa da estudiosa feminista pós-colonial. Elas também sinalizam um afastamento da máxima de Foucault, que afirma que o intelectual é irremediavelmente implicado em constelações de poder/saber. Quer as teóricas feministas pós-coloniais aceitem o insight de Foucault, que afirma que elas nunca poderão promover um programa político que represente o subalterno, quer abracem a noção gramsciana de um intelectual orgânico que pode falar pelo subalterno, nem a posição do subalterno, nem a posição do intelectual pós-colonial na luta anticolonial são aparentes. A questão do subalterno poderia também ser aplicada para crítico pós-colonial: ela/ele ocupa uma posição privilegiada na luta pela decolonização ou ela/ele está condenada ou condenado ao silêncio?

\section{TEORIA DECOLONIAL}

Embora a chegada da teoria decolonial possa ser caracterizada como a mais recente na cena anticolonial, ela tem uma visão muito mais abrangente do colonialismo que seus predecessores. Os teóricos decoloniais baseiam suas análises na colonização espanhola e portuguesa das Américas, que começou no século XVI e terminou no século XIX. O pensamento decolonial chama a atenção para as longas histórias do colonialismo espanhol e português, que tinham sido agrupadas como uma só nos debates coloniais que se concentravam exclusivamente no colonialismo britânico e francês. Na fase inicial da expansão colonial europeia, as primeiras universidades coloniais foram fundadas em Santo Domingo, em Lima, e na Cidade do México, já em 1538 e 1551. Esses centros intelectuais se tornaram lugares de debates acalorados sobre a epistemologia e historiografia eurocêntricas. Nesses debates, os intelectuais da elite criolla, mestizos e indígenas procuraram demonstrar que o conhecimento europeu era incapaz de reconhecer, muito menos compreender, as diferenças culturais e as formas de governo do Império Inca desaparecido (MENDOZA, 2014). Mais de quatro séculos antes da emergência do Revista X, v. 16, n. 1, p. 259-289, 2021. 
Grupo Sul-Asiático de Estudos Subalternos, estudiosos das universidades espanholas, como a Universidade de Salamanca e o Colegio San Gregorio, questionavam a justeza do império e da colonização. Nos famosos debates de Valladolid (1550-1551), por exemplo, Bartolomeu de las Casas e Ginés de Sepúlveda debatiam a humanidade dos ameríndios, desafiando os efeitos desumanizadores da colonização e também a retórica da salvação implantada pelos missionários espanhóis (MENDOZA, 2006). Felipe Guamán Poma de Ayala, um nobre quíchua, escreveu uma das primeiras crônicas em defesa dos ameríndios, afirmando que os espanhóis não tinham nenhum direito de controlar os assuntos andinos. O mestizo descendente da nobreza inca, Garcilaso de la Vega, tentou recuperar as vozes e preservar a memória histórica dos ameríndios ao mesmo tempo em que eles eram submetidos ao genocídio. Em um artigo sugestivo intitulado Sí, el subalterno puede hablar: un análisis breve de la 'Nueva corónica y buen gobierno' de Felipe Guamán Poma de Ayala y los 'Comentarios reales' del Inca Garcilaso de la Vega (em tradução livre para o português, "Sim, o subalterno pode falar: uma breve análise de 'Nova crônica e bom governo' de Felipe Guamán Poma de Ayala e de 'Comentários reais' de Inca Garcilaso de la Vega"), Lipi Biswas Sen, uma professora da Universidade Nehru da Índia, observa que esses relatos dos subalternos, teorizados no século XVI por Guamán Poma de Ayala e Garcilaso de la Vega, anteciparam argumentos centrais do Grupo Sul-Asiático de Estudos Subalternos. De acordo com Guamán Poma de Ayala e Garcilaso de la Vega, os ameríndios resistiram ao pensamento binário dos europeus, recusando-se a aceitar que a colonização fosse um processo civilizatório. De fato, os ameríndios inverteram a lógica da colonização, identificando os europeus como bárbaros que estavam destruindo as civilizações há tempos estabelecidas pelos povos indígenas. Em contraste à teoria subalterna Sul-Asiática que retrata o subalterno como possuidor de uma psicologia política incompatível com os saberes ocidentais, Guamán Poma de Ayala e Garcilaso de la Vega insistiam que o subalterno desenvolveu sofisticadas habilidades de aprendizado da língua espanhola e fez uso das ferramentas do senhor, como a escrita alfabética, que os incas não tinham desenvolvido previamente, para subverter os discursos colonizadores dos europeus (BISWAS SEN, 2004).

A certeza de que o subalterno pode falar é uma característica distintiva da teoria decolonial; mas pensadores decoloniais discordam da teoria pós-colonial/subalterna e do feminismo pós-colonial de várias outras formas. O Grupo Modernidade/Colonialidade insiste que o capitalismo é concomitante ao colonialismo; não é um sistema autônomo importado para as Américas sozinho. Discordando veementemente daqueles que afirmam que o capitalismo já existia na Europa antes da colonização, os teóricos decoloniais 
argumentam que o colonialismo é o que fez possível o capitalismo. Em forte contraste com aqueles que afirmam que o capitalismo falhou em se desenvolver na colônia devido a condições internas à indigeneidade, o Grupo Modernidade/Colonialidade insiste que o capitalismo requer as condições internas da colônia para se realizar.

Os teóricos decoloniais conceituam o colonialismo como o lado escuro da modernidade. Contestando a associação da modernidade aos desenvolvimentos emancipatórios na Europa, como a Reforma Protestante, o Iluminismo e a Revolução Francesa, o Grupo Modernidade/Colonialidade sugere relações causais mais complexas entre colonialismo, a era da razão e a era das revoluções. Exatamente como Hegel sugeriu que a completa realização da razão e da liberdade é inseparável do despotismo, da escravidão e da conquista, os teóricos decoloniais sugerem que a escravidão, o trabalho forçado e a carência de direitos dos povos colonizados existem em uma relação dialética com as noções liberais de liberdade, igualdade, justiça e trabalho livre. A colônia é tanto a condição de possibilidade quanto o laboratório do Estado-nação ocidental, e a cidadania que garante os direitos está ligada aos homens que possuem propriedade. Em outras palavras, a liberdade dos europeus e dos colonos depende da ausência de liberdade do colonizado. Precisamente porque a liberdade de alguns pressupõe a subordinação de outros, a decolonização é sempre um projeto inacabado. Embora o colonialismo tenha acabado na maior parte do mundo, a "colonialidade do poder" continua a definir as relações entre o Ocidente e o Remanescente.

O sociólogo peruano Aníbal Quijano teorizou a colonialidade do poder como um processo de racialização integral à colonização (2008; 2010). Começando em 1492 com a conquista das Américas, os conquistadores europeus se proclamaram os senhores do mundo, soberanos "naturais" de todos os povos "inferiores". Usando a conquista como prova de sua superioridade, os conquistadores reclassificaram populações inteiras de acordo com hierarquias cuidadosamente aperfeiçoadas, baseadas em doutrinas religiosas, fisiognomias, mitos sobre o sangue e mandatos divinos para difundir a mensagem e os meios para a salvação. Aqueles conquistados através da violência eram condenados a uma área de não-Ser, desprovidos de humanidade, direitos e autodeterminação.

De acordo com Quijano, a ideia de raça imposta aos colonizados se originou em debates que aconteceram durante a Inquisição e a Reconquista Espanhola. O princípio da "pureza de sangue" foi introduzido de modo a distinguir cristãos "reais" dos judeus e mouros convertidos. Inventando uma noção ilusória de biologia imutável que privilegiava os católicos, a Igreja Espanhola concedeu à monarquia os fundamentos para a expulsão dos mouros e dos judeus da Espanha. Embora o princípio da pureza de sangue tenha 
sido inicialmente invocado para legitimar uma hierarquia religiosa, a ideia de vincular, com profundas repercussões sociais, conceitos de superioridade a uma base biológica foi particularmente útil aos empreendimentos colonizadores que se seguiram à conquista do "Novo Mundo". Importada à América com a colonização, a ideia de uma raça naturalmente superior, identificada pelas suas crenças e ações, se mostrou uma ferramenta útil para diferenciar os colonizadores dos ameríndios e dos escravos vindos da África. Uma vez marcados como inferiores, povos conquistados e escravizados foram submetidos não só a éditos emitidos pela monarquia católica da Espanha, mas também a missões civilizatórias, esforços de "salvação" e brutal exploração laboral e sexual.

A ideia de raça implícita nos debates em torno da "pureza de sangue" fez ascender as hierarquias que reestruturaram a organização social e também as instituições e práticas públicas e privadas no "Novo Mundo". Juntando as noções de inferioridades biológica e cultural, a raça forneceu um substrato versátil para a colonialidade do poder, justificando um sistema social hierárquico que dava controle sobre recursos materiais e humanos aos colonizadores. De acordo com Quijano, a raça reordenou todos os aspectos da vida indígena, incluindo o sexo, o trabalho, a autoridade coletiva, a subjetividade e a intersubjetividade. A raça designou quem se tornaria escravo, trabalhador servil ou trabalhador assalariado livre. A raça determinou o status político durante a era colonial, e subsequentemente ditou quem teria acesso à cidadania integral no Estado-nação. Como base do eurocentrismo, a raça definiu o que valia como história e como conhecimento, e condenou os colonizados a viverem como povos sem história, sem direitos do homem e sem direitos humanos. À medida que a produção de conhecimento europeia era creditada como único conhecimento válido, as epistemologias indígenas foram sendo relegadas ao status de superstição primitiva ou destruídas. O eurocentrismo congelou as relações intersubjetivas entre os europeus e os não-europeus num quadro temporal que sempre posicionou os europeus como os mais avançados. Quer a oposição colocasse os civilizados contra os bárbaros, os assalariados contra os escravos, o moderno contra o pré-moderno ou o desenvolvido contra o subdesenvolvido, a superioridade do europeu nunca era questionada (QUIJANO, 2008).

A partir de Quijano, os pensadores decoloniais desenvolveram uma variedade de conceitos que tomam a colonialidade do poder como ponto de partida. Como Quijano, os teóricos decoloniais enfatizam que colonialidade é diferente de colonialismo. Em contraste aos atos de colonialismo historicamente específicos pelos quais uma nação impõe soberania sobre outra, a colonialidade se refere a padrões de poder de longa data que emergem no contexto do colonialismo, que definem cultura, trabalho, relações 
intersubjetivas, aspirações individuais, senso comum e produção de conhecimento, de formas que afirmam a superioridade do colonizador. Sobrevivendo muito depois de o colonialismo ter sido derrubado, a colonialidade permeia a consciência e as relações sociais da vida contemporânea. Edgardo Lander (2000) teorizou sobre a colonialidade do saber, examinando as práticas diversas com as quais o conhecimento não-ocidental tem sido, e continua sendo, silenciado ou erradicado. Apresentando algumas semelhanças com a noção criada por Spivak de violência epistêmica, Lander analisa não só a exterminação física dos produtores de conhecimento não-ocidentais como também as diversas tecnologias de genocídio intelectual. Emprestando insights de Walter Mignolo, Nelson Maldonado Torres (2008) reinterpreta os conceitos centrais da fenomenologia existencial como uma manifestação da colonialidade do ser. De fato, ele ilustra como a consciência do colonizador estrutura o cogito ocidental de formas que asseguram que aqueles de descendência europeia se recusem a reconhecer a plena humanidade de pessoas de cor. Breny Mendoza (2014) teoriza a colonialidade da democracia, ilustrando como a racialização e a atribuição de gênero (ou genderização) a homens e mulheres não-europeus têm sido essenciais para a construção da cidadania do homem branco e para a perpetuação do seu privilégio, apesar da existência de garantias constitucionais de uma igualdade formal.

\section{Feminismo decolonial}

O feminismo decolonial é algumas vezes atribuído ao estudo de feministas nativoamericanas, feministas chicanas e à teoria feminista anticolonial africana publicada nas décadas de 1960 e 1970, mas o desabrochar completo desse pensamento é muito mais recente. Borderlands/La Frontera (1987), de Gloria Anzaldúa, é frequentemente identificado como um texto fundador da teoria decolonial feminista. Seus conceitos de consciência mestiza e de pensamiento fronterizo teorizaram o caráter subversivo dos saberes subjugados que dividem epistemologia e linguagens coloniais de maneiras que mudam as condições do debate. Fortemente influenciada pela teoria pós-colonial, Emma Pérez publicou The decolonial imaginary em 1999, procurando desafiar o "imaginário colonial" que ainda sustenta a historiografia patriarcal, nacionalista e chicana. Estudiosas feministas indígenas, como Paula Gunn Allen (1986), e estudiosas anticoloniais africanas, como Oyèrónkẹ Oyěwùmí (1997), também analisaram tanto o impacto da colonização sobre as mulheres quanto os discursos colonizadores do feminismo ocidental.

O feminismo decolonial está ganhando popularidade em vários contextos culturais e nacionais. Catherine Walsh (2010), que publica tanto em inglês quanto em espanhol, Revista X, v. 16, n. 1, p. 259-289, 2021. 
analisou a interculturalidade, os saberes subjugados e a decolonialidade no Equador. Seu conceito de interculturalidade é particularmente importante para a teoria decolonial porque se esquiva de conceitos como multiculturalismo e pluriculturalismo, que foram implantados pelo Banco Mundial para promover o capitalismo neoliberal. Para Walsh, a "interculturalidade crítica" não é sobre inclusão e "se dar bem uns com os outros", mas um projeto político, ético e epistêmico da população indígena dos Andes que procura criar uma nova racionalidade e humanidade que reverta o eurocentrismo e a colonialidade do poder. Fora dos Estados Unidos, Madina Tlostanova, uma estudiosa feminista originária da Cabárdia-Balcária, uma república da Federação Russa, que agora vive em Moscou, usa um quadro decolonial para analisar o espaço e subjetividade pós-soviéticos. Tlostanova toma emprestado o conceito de diferença imperial criado por Mignolo para elucidar a posição da União Soviética dentro das narrativas ocidentais de império. Aqui, o império soviético não apenas se origina fora da modernidade e aparece como um império subalterno, mas sua exterioridade em relação à modernidade e ao imaginário europeu permite que essa diferença imperial se transforme em uma diferença colonial. Isso determina os tipos de feminismo que emergem no espaço pós-soviético que, enquanto bem definidos em termos de colonialidade, não são facilmente compreendidos nos "feminismos de cor". A maior parte de seu trabalho sobre gênero e decolonialidade, entretanto, não foi traduzida para o inglês. A crítica cultural alemã Freya Schiwy também faz uso de uma lente decolonial para investigar o conceito de gênero nos Andes e para teorizar a subjetividade e a colonialidade no campo dos estudos culturais (SCHIWY, 2010).

A teoria decolonial é muito influente na América Latina e no Caribe, embora algumas estudiosas feministas tenham questionado seu conteúdo, sua aquisição geográfica e sua lacuna a respeito do gênero. Dentro dos círculos feministas, a teoria decolonial entrou em diálogo com feministas interseccionais, pós-estruturalistas, indígenas, afrolatino-americanas e mestizas, que desenvolveram suas próprias teorias que vão além da opção decolonial. Rita Segato (2001; 2012), uma feminista e antropóloga argentina que vive no Brasil, por exemplo, integra elementos da teoria decolonial em seu trabalho, mas é crítica à noção da colonialidade de gênero porque não está convencida pela afirmação de Lugones de que as hierarquias de gênero eram desconhecidas nas sociedades indígenas. Silvia Rivera Cusicanqui, uma socióloga feminista e ativista aimará da Bolívia famosa por seu trabalho na instituição Taller de Historia Oral Andina, denunciou a teoria decolonial como discurso colonizador originado nas universidades dos Estados Unidos, que não é só dissociado das lutas locais dos povos indígenas da América Latina, mas que também desapropria e não reconhece o trabalho de décadas que foi feito na região sobre 
a colonização e a decolonização (CUSICANQUI, 2010, p. 58). A teoria decolonial na América Latina também tem sido submetida a uma dupla crítica feminista. Uma de suas dimensões concentra-se na falta de atenção ao conceito de gênero ou na conceitualização inadequada de gênero encontrada na teoria decolonial - particularmente, nas teorias de Quijano e Dussel (LUGONES, 2007; 2014; MENDOZA, 2010).

A teoria decolonial também tem ganhado impulso na academia feminista estadunidense, embora não tenha tido o sucesso imediato que a teoria pós-colonial teve nos anos 1990. Em duas publicações recentes, Heterosexualism and the colonial/ modern gender system (em tradução livre para o português, "Heterosexualismo e o sistema colonial/moderno de gênero") (2007) e "Rumo a um feminismo decolonial" (2014), María Lugones apresentou a teoria decolonial para o público feminista nos Estados Unidos, enquanto expandia seus parâmetros para abranger a colonialidade do gênero e da sexualidade. Em seu ensaio de 2007, Lugones une a interseccionalidade e a colonialidade do poder de Quijano para continuar desenvolvendo sua própria concepção da colonialidade de gênero. Ela critica a concepção de gênero criada por Quijano por diversos motivos: estar ainda preso ao determinismo biológico; pressupor dimorfismo sexual onde não existia; naturalizar a heteronormatividade em culturas que não consideravam a homossexualidade como transgressão sexual ou social; e presumir uma distribuição de poder patriarcal em sociedades onde relações sociais mais igualitárias entre homens e mulheres eram prevalentes. Na visão de Lugones, o entendimento de Quijano sobre gênero ainda é eurocêntrico. Emprestando alguns insights do estudo feminista indígena e da obra de Oyěwùmí sobre o povo iorubá para corrigir a mal concebida noção de gênero de Quijano, Lugones argumenta que as sociedades indígenas não tinham "gênero" antes da invasão europeia. $O$ gênero não existia como um princípio organizacional de poder nas sociedades indígenas antes do processo de colonização. Outros princípios, como senioridade, forneciam a base para o poder e a autoridade, mas eles eram muito distintos da construção social do gênero. Ao invés de considerar o gênero como uma característica perene da organização social, Lugones argumenta que ele deve ser entendido como um construto social, da mesma maneira que a raça foi uma imposição europeia. No processo de colonização, mulheres e homens na colônia foram ambos racializados e sexualizados ao mesmo tempo em que o gênero foi implantado como uma poderosa ferramenta para destruir as relações dos colonizados através da separação de homens e mulheres e da criação de antagonismos entre eles. Construções de gênero europeias introduziram hierarquias internas que quebraram a solidariedade entre homens e mulheres, destruindo laços anteriores baseados na complementaridade e reciprocidade. No lugar de uma 
colaboração harmoniosa, os colonizadores europeus posicionaram homens e mulheres como antagonistas. Por meio da violência sexual, exploração e sistemas de concubinagem, os colonizadores usaram o gênero para quebrar a vontade de homens e mulheres indígenas, impondo novas hierarquias que foram institucionalizadas com o colonialismo. Os corpos das mulheres se tornaram o terreno em que homens indígenas negociavam sobrevivência sob as novas condições coloniais. Sacrificar mulheres indígenas para a luxúria dos conquistadores, perversamente, se tornou o único meio de sobrevivência cultural. Lugones nomina essa violência sexual sistêmica o lado escuro do sistema de gênero moderno/colonial.

Julieta Paredes (2008) promove uma crítica ao conceito de colonialidade de gênero criado por María Lugones, sugerindo que a análise de Lugones deixa escapar a centralidade do gênero para sociedades indígenas patriarcais existentes antes da colonização europeia. Lugones dá mais um passo com sua análise em seu ensaio de 2010, "Rumo a um feminismo decolonial", afirmando que o sistema de gênero imposto por colonizadores europeus aos colonizados diferia significativamente do sistema de gênero que os conquistadores impunham às mulheres europeias que viviam na colônia. O sistema de gênero multifacetado imposto na colônia subordinava mulheres europeias, mas desumanizava homens e mulheres indígenas, escravos africanos e mestizos pobres. Aceitando o princípio central da colonialidade - que a separação de humanos dos nãohumanos foi concomitante à colonização, Lugones sugere que a racialização de nãoeuropeus como bestas de carga teve consequências críticas para o desenvolvimento de complexos sistemas de sexo e gênero. As dicotomias hierárquicas que diferenciavam o ser humano civilizado do primitivo natural e a cultura, da natureza, estruturaram não apenas as relações entre colonizador e colonizado, mas também legitimaram uma hierarquia que elevou os homens europeus sobre as mulheres europeias. O ser humano em si mesmo estava bifurcado: como criaturas mais próximas da natureza, mais emocionais que racionais, fadadas à função animal da reprodução, as mulheres europeias estavam abaixo dos homens na grande Cadeia do Ser, mas ainda eram humanas, marcadas pela cultura. $\mathrm{O}$ gênero civilizado envolvia uma hierarquia que subordinava mulheres europeias a homens europeus, mas ainda marcava um abismo entre colonizadores e colonizados. Como selvagens, os colonizados manifestavam diferença biológica (o sexo), mas não tinham um sistema de gênero. Relações igualitárias entre homens e mulheres indígenas foram interpretadas pelos europeus como uma evidência de barbárie. De acordo com Lugones, portanto, a hierarquia de gênero marca o status civilizado de mulheres e homens europeus; sua ausência define o não-humano, o racializado, os não-europeus naturalizados, que são 
sexuados, mas não possuem gênero. Quer retratados como animais hipersexualizados ou burros de carga, os povos indígenas e os povos escravizados eram imaginados como sendo uma ameaça à ordem de gênero europeia. Como seres sub-humanos, os colonizados serviam para procriação, trabalho bruto, exploração e/ou massacre (LUGONES, 2014). A colonialidade de gênero deixa claro que o gênero garante um status civilizado apenas para aqueles homens e mulheres que habitam o domínio humano; aqueles que não possuem gênero estão sujeitos à exploração bruta ou ao completo genocídio. Assim, a teoria de Lugones da colonialidade de gênero como uma prática desumanizadora que sobrevive à colonização ajuda a coompreender questões contemporâneas como o feminicídio, o tráfico humano e a violência crescente contra mulheres não-europeias.

$\mathrm{Na}$ América Latina e no Caribe, a análise de Lugones da colonialidade de gênero teve uma recepção variada. Seu trabalho abriu o arquivo feminista para o pensamento decolonial e gerou um número respeitável de seguidores. Ainda assim, suas afirmações sobre a colonialidade de gênero são controversas entre feministas mainstream, feministas indígenas e estudiosas feministas que trabalham com a colonização e a decolonização dentro de outros quadros teóricos (MENDOZA, 2014). Algumas críticas questionam a validez do trabalho etnográfico que Lugones usa para sustentar seus argumentos. A antropóloga argentina Rita Laura Segato (2001), por exemplo, usa sua própria pesquisa sobre o povo iorubá na América Latina para questionar a afirmação de Oyěwùmí sobre a inexistência do gênero entre os iorubás. Embora ela reconheça que o sistema de gênero dos iorubás seja complexo e diferente do gênero europeu e que sua forma de patriarcado era, de várias maneiras, menos intensiva que a versão europeia, Segato fornece ampla evidência de que o gênero existia como um status de diferenciação opressivo entre os iorubás. A pesquisadora sugere que patriarcados de baixa intensidade se tornavam mais hierárquicos quando submetidos à lógica do gênero imposta sob a colonização - com consequências devastadoras para mulheres indígenas. Enquanto as esferas pública e privada eram separadas e atribuídas a um gênero, mulheres indígenas eram domesticadas e privatizadas, perdendo o poder que uma vez tiveram na comunidade. Embora os homens indígenas mantivessem alguma autoridade comunal, foram humilhados e simbolicamente emasculados pelas depredações da colonização. Forçados a se engajar na lógica de gênero europeia, os homens indígenas retornaram às suas comunidades suplementando o léxico antigo de poder com novos códigos hierárquicos (SEGATO, 2012).

Silvia Rivera Cusicanqui (2004) nos fornece uma crítica similar baseada nas experiências da sociedade andina. Embora as relações de gênero indígenas fossem mais igualitárias, tanto na esfera privada quanto na pública, o sistema de gênero andino 
era organizado em torno do casal heterossexual normativo dentro de um sistema de complementaridade. Sistemas de parentesco eram bilaterais, o que dava a mulheres e homens direitos de herança iguais. Mulheres e homens alcançavam identidade social quando formavam um casal e ambos acumulavam prestígio com o decorrer da idade. Cusicanqui observa que todas essas práticas foram enfraquecidas ou destruídas, não durante a colonização, mas com o advento de sistemas republicanos de governo, modernidade e desenvolvimento. O papel das mulheres na comunidade foi enfraquecido, mas muito mais recentemente do que o relato de Lugones sobre a colonialidade de gênero sugere (CUSICANQUI, 2004). De acordo com Cusicanqui, as relações de gênero baseadas na complementaridade sobreviveram nas comunidades indígenas por muito mais tempo do que se tinha presumido previamente, destruídas em um processo gradual de patriarcalização que acompanhou a modernização e a invasão do Estado-nação moderno nas comunidades andinas.

Na Bolívia, desde a eleição de Evo Morales como presidente, a primeira pessoa indígena a ocupar o cargo, e no México, com as lutas revolucionárias zapatistas, o debate sobre se o gênero precedeu ou não a colonização tem tido um papel importante, influenciando teorias revolucionárias e propostas feministas para medidas de Estado, leis e práticas, além de imaginários políticos. Fora dessas lutas políticas, a questão sobre se o gênero é um construto colonial ou prática ancestral talvez ofereça um falso dilema. $\mathrm{O}$ conceito criado por Lugones da colonialidade de gênero, a afirmação de Segato de que os patriarcados de baixa intensidade estabelecidos antes da conquista foram exacerbados pela colonização e o relato de Cusicanqui sobre a patriarcalização como consequência da formação do Estado-nação na pós-independência não precisam ser entendidos como contraditórios. Todas essas três estudiosas concordam que a imposição de um sistema de gênero europeu teve efeitos profundos nas relações entre homens e mulheres na colônia, desencadeando forças contra mulheres indígenas, escravizadas e mestizas pobres, letais o suficiente para serem consideradas genocidas. A conceitualização de Lugones da colonialidade de gênero é útil precisamente porque situa o gênero em relação à lógica genocida da colonialidade do poder. A lógica racializante que os europeus impuseram sobre os colonizados roubou dos não-europeus não só o seu status de humanos, mas também o seu status de seres possuidores de gênero. Desprovidos de humanidade e de gênero, os nãoeuropeus eram não só infinitamente exploráveis, como também elimináveis. Os insights de Lugones se assemelham àqueles das estudiosas feministas indígenas estadunidenses que há tempos afirmam que o Estado-nação colonial de povoamento operava de acordo 
com uma lógica de eliminação, o que possibilitou o quase completo desaparecimento físico e simbólico dos povos ameríndios.

Quer seja tirado de Lugones, de estudiosas feministas indígenas dos Estados Unidos ou de estudiosas feministas latino-americanas, o pensamento decolonial nos ensina importantes lições. A lógica racializante introduzida nas Américas em 1492 fez muito mais do que estruturar uma relação entre colonizador e colonizado; ela estabeleceu formas de pensar e modos de poder que moldaram e continuam a moldar as relações sociais e políticas que permeiam todos os aspectos da vida. Reconhecer a profunda influência da racialização e da atribuição de gênero é essencial para um entendimento adequado do passado, para os esforços de transformar o presente e para as estratégias de visionar e produzir um futuro diferente.

\section{REFERÊNCIAS}

ABU-LUGHOD, LILA. As mulheres muçulmanas precisam realmente de salvação?: reflexões antropológicas sobre o relativismo cultural e seus outros. Revista Estudos Feministas, Florianópolis, v. 20, n. 2, p. 451-470, ago. 2012. Disponível em: <https:// www.scielo.br/scielo.php?script=sci_arttext\&pid=S0104-026X2012000200006\&lng=en $\& n r m=i s o>$. Acesso em: 30 abr. 2020.

ALEXANDER-FLOYD, Nikol G. Disappearing acts: reclaiming intersectionality in the social sciences in a post-black feminist era. Feminist Formations, v. 24, n. 1, p. 1-24, primavera 2012.

ALLEN, Paula Gunn. The sacred hoop: recovering the feminine in American Indian traditions. Boston: Beacon Press, 1986.

ANZALDÚA, Gloria. Borderlands/La frontera: the new mestiza. São Francisco: Aunt Lute Books, 1987.

AYALA, Felipe Guamá Poma de. Nueva corónica y buen gobierno. Paris: Institut d'ethnologie, 1936.

CÉSAIRE, Aimé. Discurso sobre o colonialismo. Florianópolis: Letras Contemporâneas, 2017.

CHIBBER, Vivek. Postcolonial theory and the specter of capital. Londres: Verso, 2013.

CHO, Sumi; CRENSHAW, Kimberlé; MCCALL, Leslie. Intersectionality: theorizing power, empowering theory. Signs: Journal of Women in Culture and Society, Chicago, v. 
38, n. 4, p. 785-810, verão 2013.

COLlinS, Patricia Hill. Pensamento feminista negro: conhecimento, consciência e a política do empoderamento. São Paulo: Boitempo, 2019.

COLLINS, Patricia Hill. Toward a new vision: race, class, and gender as categories of analysis and connection. Race, Gender and Class, v. 1, n. 1, p. 25-45, outono 1993.

CRENSHAW, Kimberlé. Demarginalizing the intersection of race and sex: a black feminist critique of antidiscrimination doctrine, feminist theory and antiracist politics. University of Chicago Legal Forum, Chicago, n. 140, p. 139-167, 1989.

CUSICANQUI, Silvia Rivera. Ch'ixinakax Utxiwa: Una reflexión sobre prácticas y discursos descolonizadores. Buenos Aires: Tinta Limón y Retazos, 2010.

CUSICANQUI, Silvia Rivera. La noción de "derecho" o las paradojas de la modernidad postcolonial: indígenas y mujeres en Bolivia. Revista Aportes Andinos, Quito, p. 1-9, out. 2004.

DU BOIS, W. E. B. As almas da gente negra. São Paulo: Lacerda, 1999.

DUSSEL, Enrique. Philosophy of liberation. Nova York: Orbis Books, 1985.

FANON, Frantz. Os condenados da terra. Juiz de Fora: Editora UFJF, 2006.

FERNANDES, Leela. Transnational feminism in the United States. Nova York: New York University Press, 2013.

GANDHI, Leela. Postcolonial theory. Nova York: Columbia University Press, 1998.

GARRY, Ann. Who is included? Intersectionality, metaphors, and the multiplicity of gender. In: CRASNOW, Sharon L.; SUPERSON, Anita M. (Ed.). Out from the shadows: analytical feminist contributions to traditional philosophy. Nova York: Oxford University Press, 2012. p. 493-530.

GROSFOGUEL, Ramon. 2010. The epistemic decolonial turn: beyond political economy paradigms. In: MIGNOLO, Walter D.; ESCOBAR, Arturo (Ed.). Globalization and the decolonial option. Londres: Routledge, 2010. p. 65-77.

GUNNARSON, Lena. A defense of the category "women". Feminist Theory, v. 12, n. 1, p. 23-27, 2011.

HANCOCK, Ange-Marie. Beyond the oppression Olympics: a politics of solidarity for Revista X, v. 16, n. 1, p. 259-289, 2021. 
the 21st century. New York: Palgrave Macmillan, 2011.

JORDAN-ZACHERY, Julia S. Am I a black woman or a woman who is black? A few thoughts on the meaning of intersectionality. Politics \& Gender, Cambridge, v. 3, n. 2, p. $254-263$, jul. 2007.

KONTOPOUlOS, Kyriakos. The logic of social structures. Cambridge: Cambridge University Press, 1993.

LANDER, Edgardo. La colonialidad del saber: eurocentrismo y ciencias sociales. Perspectivas Latinoamericanas. Buenos Aires: CLACSO, 2000.

LEITCH, Vincent B. (Ed.). The Norton anthology of theory and criticism. New York: W. W. Norton, 2010.

LEWIS, Reina; MILLS, Sara. Feminist postcolonial theory. New York: Routledge, 2003.

LUGONES, Maria. Heterosexualism and the colonial/modern gender system. Hypatia, Cambridge, v. 22, n. 1, p. 186-209, inverno 2007.

LUGONES, Maria. Rumo a um feminismo descolonial. Revista Estudos Feministas, Florianópolis, v. 22, n. 3, p. 935-952, 2014.

MALDONADO-TORRES, Nelson. Against war: views from the underside of modernity. Durham: Duke University Press Books, 2008.

MARIÁTEGUI, José Carlos. Sete ensaios de interpretação da realidade peruana. São Paulo: Expressão Popular, 2008.

MAY, Vivian M. "Speaking into the void"? Intersectionality critiques and epistemic backlash. Hypatia, Cambridge, v. 29, n. 1, p. 94-112, inverno 2014.

MCCALL, Leslie. The complexity of intersectionality. Signs: Journal of Women in Culture and Society, Chicago, v. 30, n. 3, p. 1771-1800, 2005.

MCCLINTOCK, Anne. Couro imperial. Campinas: Ed. da Unicamp, 2010.

MENDOZA, Breny. Ensayos de crítica feminista en nuestra América. México D. F.: Editorial Herder, 2014.

MENDOZA, Breny. La epistemologia del sur, la colonialidad de género y el feminismo latinoamericano. In: MIÑOSO, Yuderkys Espinosa (Ed.). Aproximaciones críticas a las prácticas teórico-políticas del feminismo latinoamericano. Buenos Aires: En la Frontera, 
2010. v. 1, p. 19-36.

MENDOZA, Breny. The undemocratic foundations of democracy: an enunciation from postoccidental Latin America. Signs: Journal of Women in Culture and Society, Chicago, v. 31, n. 4, p. 932-939, verão 2006.

MENDOZA, Breny. Transnational feminisms in question. Feminist Theory, v. 3, n. 3, p. 295-314, 2002.

MIGNOLO, Walter. Histórias locais/projetos globais: colonialidade, saberes subalternos e pensamento liminar. Belo Horizonte: Editora UFMG, 2003.

MIGNOLO, Walter. The darker side of the Rennaissance: literacy, territoriality, and colonization. Ann Arbor: University of Michigan Press, 1995.

MOHANTY, Chandra T. Under Western eyes: feminist scholarship and colonial discourses. In: ; TORRES, Lourdes M.; RUSSO, Ann (Ed.). Third world women and the politics of feminism. Bloomington: Indiana University Press, 1991. p. 51-80.

MOHANTY, Chandra T.; RUSSO, Ann; TORRES, Lourdes (Ed.). Third world women and the politics of feminism. Bloomington: Indiana University Press, 1991.

NASCIMENTO, Tatiana. Quem nomeou essas mulheres "de cor"? Políticas feministas de tradução que mal dão conta das sujeitas negras traduzidas. Translatio, Porto Alegre, n. 13, p. 127-142, 2017.

NKRUMAH, Kwame. Consciencism. New York: Monthly Review Press, 1964.

ORTEGA, Mariana. Being lovingly, knowingly ignorant: white feminism and women of color. Hypatia, Cambridge, v. 21, n. 3, p. 56-74, verão 2006.

OYĚWÙMÍ, Oyèrónkẹ. The invention of women: making an African sense of Western gender discourses. Mineápolis: University of Minnesota Press, 1997.

PAREDES, Julieta. Hilando fino desde el feminism comunitario. La Paz: Comunidad Mujeres Creando Comunidad, 2008.

PAUDYAL, Mahesh; PRASAI, Ujjwal. The dream of a borderless world. The Kathmandu Post, Kathmandu, 24 dez. 2011. Disponível em: <https://maheshpaudyal.blogspot. com/2017/12/the-dream-of-borderless-world.html>. Acesso em: 3 maio 2020.

PÉREZ, Emma. The decolonial imaginary: writing Chicanas into history. Bloomington: Revista X, v. 16, n. 1, p. 259-289, 2021. 
Indiana University Press, 1999.

QUIJANO, Aníbal. Coloniality and modernity/rationality. In: MIGNOLO, Walter D.; ESCOBAR, Arturo (Ed.). Globalization and the decolonial option. London: Routledge, 2010. p. 22-32.

QUIJANO, Aníbal. Coloniality of power, Eurocentrism, and social classification. In: MORAÑA, Marel et al. (Ed.). Coloniality at large. Durham: Duke University Press, 2008. p. 181-224.

ROSHANRAVAN, Shireen. Motivating coalition: women of color and epistemic disobedience. Hypatia, Cambridge, v. 29, n. 1, p. 41-58, inverno 2014.

SANTA CRUZ FEMINIST OF COLOR COLLECTIVE. 2014. Building on "the edge of each other's battles": a feminist of color multidimensional lens. Hypatia, Cambridge, v. 29, n. 1, p. 23-40, inverno 2014.

SCHIWY, Freya. Decolonization and the question of subjectivity: gender, race, and binary thinking. In: MIGNOLO, Walter D.; ESCOBAR, Arturo (Ed.). Globalization and the decolonial option. London: Routledge, 2010. p. 125-148.

SEGATO, Rita. Gênero e colonialidade: em busca de chaves de leitura e de um vocabulário estratégico descolonial. E-cadernos CES, Coimbra, n. 18, p. 106-131, 2012. Disponível em: <https://journals.openedition.org/eces/1546?file=1>. Acesso em: 4 maio 2020.

SEGATO, Rita. The factor of gender in the Yoruba transnational religious world. Série Antropologia, Brasília, n. 289, 2001.

SEN, Lipi Biswas. Sí, el subalterno puede hablar: un análisis breve de la "Nueva corónica y buen gobierno" de Felipe Guaman Poma de Ayala y los "Comentarios reales" del Inca Garcilaso de la Vega. La Torre - Revista de la Universidad de Puerto Rico, San Juan, n. 34, p. 475-502, out./dez. 2004.

SHOHAT, Ella; STAM, Robert. Flagging patriotism. New York: Routledge, 2006.

SPIVAK, Gayatri Chakravorty. Pode o subalterno falar?. Belo Horizonte: Editora UFMG, 2018.

STAM, Rober; SHOHAT, Ella. Race in translation. New York: New York University Press, 2012. 
STOLER, Ann Laura. Carnal knowledge and imperial power: race and the intimate in colonial rule. Berkeley: University of California Press, 2002.

TUCK, Eve; YANG, K. Wayne. 2012. Decolonization is not a metaphor. Decolonization: Indigeneity, Education \& Society, Toronto, v. 1, n. 1, p. 1-40, 2012.

VEGA, Inca Garcilaso de la. 2008. Comentarios reales. Barcelona: Linkgua Ediciones, 2008.

WALSH, Catherine. Shifting the geopolitics of critical knowledge: decolonial thought and cultural studies "others" in the Andes. In: MIGNOLO, Walter D.; ESCOBAR, Arturo (Ed.). Globalization and the decolonial option. London: Routledge, 2010. p. 78-93.

ZACK, Naomi. Inclusive feminism: a third wave theory of women's commonality. Lanham: Rowman \& Littlefield, 2005. 